\title{
Lisää yritysten ja koulutusorganisaatioiden yhteistyötä
}

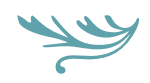

AikUiSKOULUTUSJÄRJESTELMÄMME lienee edelleen eräs maailman parhaita, ellei parhain. Suomalaiset aikuiset ovat ahkeria oppijoita. Tarjontaa on niin täydennyskoulutuskeskuksissa, avoimessa korkeakouluopetuksessa, kesäyliopistoissa kuin kansalais- ja työväenopistoissa ja muualla vapaan sivistystyön oppilaitoksissa. Suomalaisissa yrityksissä työskentelevät osallistuvat henkilöstökoulutukseen useammin kuin henkilöstö EU:ssa keskimäärin.

Onko kaikki aikuiskoulutuksessa siis hyvin? Kokonaisuus voisi toimia yhteen entistä paremmin. Erityisesti siinä olisi parantamisen varaa, ettemme me aikuiskoulutuksen eri sidosryhmät ja osapuolet puhuisi niin paljon toinen toistemme ohi ja toinen toisillemme vieraalle kielellä. Kielitaito-ongelmia syntyy erityisesti, kun puhumme työelämässä tapahtuvasta oppimisesta. Toiset katsovat aikuiskoulutusta virallisen tutkintojärjestelmämme silmälaseilla, me elinkeinoelämässä korostamme aikuisten oppimisen työelämälähtöisyyttä, monimuotoisuutta ja joustavuutta.

Elinkeinoelämän keskusliitto EK seuraa säännöllisin väliajoin henkilöstön osaamisen kehittämistä yrityksissä. Tuorein raportti (kuva 1) kuvaa vuoden 2012 tilannetta. Tutkintoon johtamaton koulutus saa henkilöstökoulutuksen ykkössijan, mutta osaamisen kehittäminen sisältää kasvavan määrän erilaisia joustavan työssä oppimisen muotoja. Työssä perehdytään ja opitaan uusia toimintatapoja sekä jaetaan ja jalostetaan tietoa yhdessä.

Tutkintoonkin johtavaa koulutusta on reilussa kolmasosassa yrityksissä. Ne ovat suurimmaksi osaksi ammatillista osaamista kehittäviä ammatti- ja erikoisammattitutkintoja, niiden joukossa myös esimerkiksi johtamisen erikoisammattitutkinnot.
Henkilöstökoulutuksessa puhutaan eri kielellä kuin esimerkiksi korkeakoulutuksen tutkintotavoitteisessa koulutuksessa. Henkilöstökoulutuksessa ei useinkaan käytetä esimerkiksi sellaista käsitettä kuin opintopiste. Korkeakoulumaailma voi kysyä, voiko oppimista ollenkaan tapahtua, ellei kerry opintopisteitä?

Henkilöstökoulutuksessa ei myöskään tyypillisesti näy käsitettä osaamistavoite. Arviointikin saattaa osassa koulutuksia olla vähän niin ja näin.

\section{PEDAGOGISTA OSAAMISTA KANNATTAISI JAKAA}

Kielitaito-ongelmat eivät olisi muuten niin vahingollisia, elleivät ne vaikeuttaisi oikean tilannekuvan laadintaa. Puhuminen toinen toistemme ohi saattaa nimittäin viedä meitä vääriin johtopäätöksiin.

Mielestäni henkilöstökoulutusta aliarvostetaan. Siitä puhutaan "lyhytkurssituksena". Esiintyy vaatimuksia, että tutkintotavoitteista koulutusta pitäisi aikuiskoulutuksessa voimakkaasti lisätä. Osaaminen ei muuten näiden näkemysten mukaan pysy ajan hermolla. Yritysten kilpailukyky jopa vaarantuisi, ellei tutkintojärjestelmään saada lisää työelämän tarvitsemaa osaamisen kehittämistä. Toisaalta virallisen tutkintojärjestelmän puitteissa tapahtuvaa koulutusta pidetään meillä elinkeinoelämässä helposti jäykkänä, kaavamaisena ja ylimitoitettuna.

Mahtaako korkeakoulujen tutkintotavoitteinen koulutus pystyä ollenkaan seuraamaan työelämän muutosten nopeaa tempoa, kysymme.

Henkilöstökoulutuksen ja tutkintotavoitteisen koulutuksen välillä voi vallita pahimmassa tapauksessa syvä juopa myös siksi, että toista toteuttavat valtaosin markkinaehtoisesti toimivat yritykset, toista valtaosin verorahoitteisesti toimivat. Yrittäjyydes- 
Kuva 1. Osaamisen kehittämisen tavat EK:n jäsenyrityksissä.

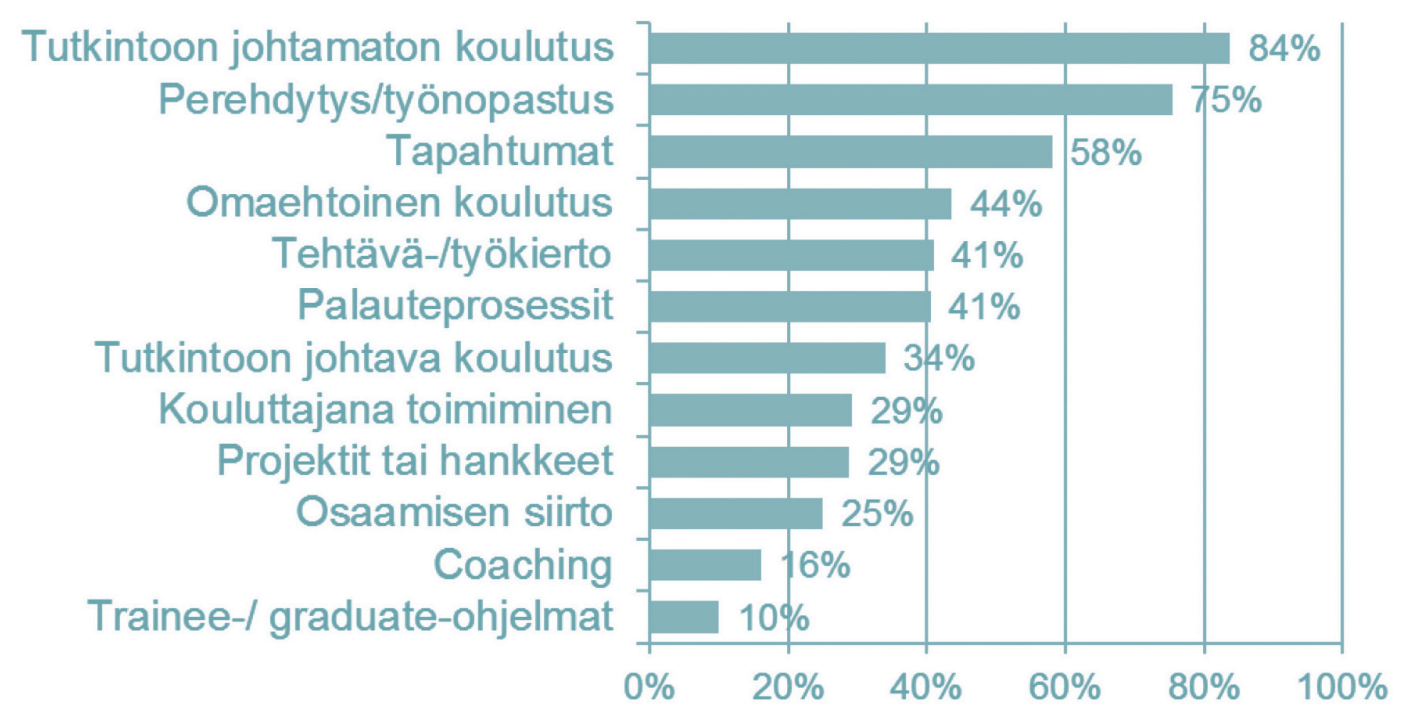

Lähde. EK:n henkilöstö- ja koulutustiedustelu 2012

tä puhutaan Suomessa ylätasolla kovin lämpimästi. Koulutuksesta puhuttaessa sävy usein muuttuu.

Havaitsen välillä sellaista ideologiaa, että yritys olisi kouluttajana jotenkin vähemmän arvokas. Ikään kuin yritysten tarjoama koulutus ei olisi osa sivistystehtävää. Usein kuulee myös, että yritysten tarjoama henkilöstökoulutus antaisi vain kapeat, tiettyyn tarkoitukseen rajatut osaamiseväät. Tutkintokoulutus sen sijaan olisi sitä universaalia ja kaikkivoipaa. Näin siitäkin huolimatta, että esimerkiksi EK:n Oivallus-ennakointihankkeen korostamat osaamistavoitteet luovuudesta, innovatiivisuudesta, yhteistyö-, esiintymis- ja ongelmanratkaisutaidoista ovat varsin yleisiä henkilöstökoulutuksen teemoja. Mikä voisi olla universaalimpaa?

Kieliongelmat ja kyvyttömyys ymmärtää toinen toistemme lähtökohtia estävät meitä saamasta aikuiskoulutuksesta kaikkia tehoja irti. Yritysten ja koulutusorganisaatioiden yhteistyö voisi olla nykyistä tuloksellisempaa. Pedagogista osaamista voisi jakaa puolin ja toisin. Korkeakouluissa on rautaisia henkilökohtaistamisen ja arvioinnin ammattilaisia. Yritykset voisivat oppia heiltä paljon. Käytäntö pitäisi nykyistä paremmin kytkeä teoriaan, ja toisin päin. Oppijat itse voisivat saada paremmin näkyväksi sen, mitä ovat oppineet. Osaamisen johtaminen tarvitsisi uusia työkaluja.

\section{LAINSÄÄDÄNTÖÄ PITÄÄ VIELÄ UUDISTAA}

Markkinaehtoisen yritysten ja myös korkeakoulujen täydennyskoulutuskeskusten tarjonta pitäisi saada nykyistä paremmin pelaamaan yhteen hiileen. Tämä täytyy huomioida tarkemmin myös aikuiskoulutuksen lainsäädäntöä uudistettaessa. Mielestäni tavoite ei toteutunut ollenkaan hyvin esimerkiksi tuoreessa korkeakoulutettujen erikoistumiskoulutusta koskevassa lainsäädännössä. Siinä luodaan osaamisen tarjontaa alueille, joilla ei ole markkinaehtoisesti tuotettua koulutustarjontaa.

Kokonaan auki jää, miten osaamisen aukko todetaan. Jää täysin epäselväksi, mitä tapahtuu, kun markkinaehtoinen koulutustarjonta kehittyy ja markkinoille tulee uusia innovatiivisia palveluita. Kielletäänkö uudistuminen, koska osaaminen hoituu jo erikoistumiskoulutuksilla? Pitääkö erikoistumiskoulutukset vuorostaan lopettaa, jos markkinaehtoinen koulutustarjonta kuitenkin jostain syystä laajenee sen "tontille"? Erikoistumiskoulutusta koskeva lainsäädäntö ei ole omiaan kuromaan edellä kuvaamaani juopaa umpeen, vaan saattaa jopa syventää sitä.

Lainsäädäntöä laadittaessa pitäisi ymmärtää, miten innovatiivisesta ja nopeasti kehittyvästä toimialas- 
ta on kyse, kun puhutaan osaamisen kehittämisestä. Sitä ei voi betonoida "luetteloon", joka erikoistumiskoulutusten tiimoille suunnitellaan. Innovatiiviset oppimisratkaisut kuuntelevat koko ajan asiakkaiden tarpeita, ja ne kehittyisivät parhaiten yksityisen ja julkisen sektorin yhteistyönä.

\section{YRITYSTEN KANNATTAISI LIITTOUTUA}

Konsulttiyhtiö McKinsey ennakoi vuonna 2012 ilmestyneessä raportissaan Transforming learning through m-education pelkästään mobiililaitteita hyödyntävien oppimisratkaisujen markkinan kasvavan vuoteen 2020 mennessä noin 64 miljardiin euroon (USD 70 billion).

Myös aikuisten oppimiseen tulee aivan erilaista tarjontaa kuin nyt. Kaupallisia toimijoita on yhä enemmän. Syntyy aidosti kansainvälinen markkina. Uskon, että aikuisille oppimisratkaisuja tarjoavat tahot kehittävät mekanismeja, joiden avulla muuallakin kuin tutkintoon johtavassa koulutuksessa saadaan oppimistulokset näkyviksi. Se hyödyttää sekä urallaan etenemiseen pyrkivää aikuisopiskelijaa että yrityksiä, joiden henkilöstö kehittää osaamistaan.

Suomalaisten korkeakoulujen ja aikuisten osaamista kehittävien yritysten kannattaisi liittoutua yhteen, jotta niin mobiilia oppimista kuin muutenkin uudenaikaista teknologiaa hyödyntävää koulutusta syntyisi myös Suomessa. Kyse on myös työllisyydestä. Emme saa jäädä kehityksestä jälkeen. Tarvitsemme Suomeen aikuisten oppimiseen erikoistuneita hyviä työpaikkoja jatkossakin.

\section{TOIVEET AIKUISKOULUTUKSEN TULEVAISUUDELLE}

EK julkaisi jo miltei 10 vuotta sitten raportin, jossa visioitiin elinikäisen oppimisen tulevaisuuden ratkaisuja (Elinkeinoelämän keskusliitto EK 2006, Tulevaisuusluotain, loppuraportti). Teimme yhteistyötä Tuomo Kuosan kanssa, joka julkaisi samaan aikaan Futura-lehdessä 1/2006 artikkelin otsikolla 40-vuoden tutkintomalli.

Hyödynnän näitä ajatuksia tähän loppuun ja kiteytän omia toiveitani aikuiskoulutuksen kehittämiseksi seuraavan 10 vuoden tarpeisiin. Näkemyksiä ei ole käsitelty EK:n kannanmuodostusproses- sissa vaan ne edustavat erään ennakointiprojektin (Tulevaisuusluotain) tuloksia.

Ensimmäinen toive olisi jo edellä kirjoitetun perusteella, että korkeakoulut ja markkinaehtoinen osaamisen kehittäminen loisivat oppijoille ratkaisuja yhdessä, ja että lainsäädäntö tunnustaisi molempien olemassaolon ja tärkeyden myös tulevaisuudessa.

Toiveeni ulottuu rakenteiden ulkopuolelle koko aikuiskoulutuksen käsitteeseen asti. Ettei enää puhuttaisi erikseen nuorten ja aikuisten koulutuksesta, vaan elinikäisestä oppimisesta. Että olisi elämän eri vaiheissa entistä modulaarisempaa koulutustarjontaa, joka tarjoaisi ratkaisuja työelämän tarpeisiin perustuviin yksilöllisiin oppimispolkuihin.

Toivoisin erilaisia keinoja osoittaa osaaminen, joka mahdollistaisi oppimispolulla etenemisen ja polulta toiselle siirtymisen. Osaamisista kertyisi eri taidoista profiili-oppimispassiin. Oppijoiden avuksi ja heille tarjolle olisi kehitetty valmiiksi erilaisia polkuja, erilaisia osaamisprofiileja tuottavia "tutkintoja". Tämä "tutkintorakenne" ei olisi stabiili vaan muokkautuisi työelämän muutosta ennakoiden. Oppijat saisivat oppimispoluille määriteltyyn tasoon asti julkista rahoitusta oppimisen tuloksellisuuden ja vaikuttavuuden perusteella. Julkista rahoitusta olisi mahdollisuus täydentää yksityisellä rahoituksella. Ihminen itse olisi aktiivinen oppimisen käytännön toteutukseen vaikuttava toimija.

Yllä kuvatun kaltaista ajattelua olen viime aikoina kuullut, siis vuonna 2015, eri tahoilta. Olisiko nyt aika pistää visio täytäntöön?

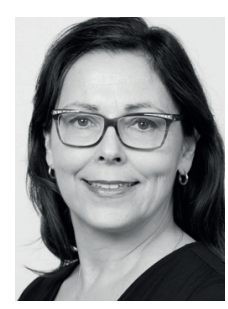

Marita Aho asiantuntija, työmarkkinat Elinkeinoelämän keskusliitto EK 